\title{
PENINGKATAN APRESIASI PUISI DALAM PEMBELAJARAN PUISI DENGAN MEDIA MUSIK DI SMA NEGERI 11 YOGYAKARTA
}

\author{
Dwi Astuti Indriati ${ }^{1)}$, Haryadi $^{2)}$ \\ SMA Negeri 1 Kalasan Sleman ${ }^{1)}$, Universitas Negeri Yogyakarta ${ }^{2)}$ \\ dwiastuti_indriati@yahoo.com ${ }^{1)}$, prof_haryadi@yahoo.co.id ${ }^{2)}$
}

\begin{abstract}
Abstrak
Masalah penelitian ini adalah kesulitan siswa dalam proses pembelajaran puisi dan peningkatan hasil apresiasi puisi. Penelitian ini bertujuan untuk meningkatkan proses dan hasil apresiasi puisi dalam pembelajaran puisi dengan media musik. Penelitian ini menggunakan model penelitian tindakan kelas dengan dua siklus. Hasil penelitian ini menunjukkan ada peningkatan pada proses dan hasil. Peningkatan proses ditandai dengan (1) keaktifan siswa dalam pembelajaran lebih banyak, (2) kerja sama siswa dalam mengerjakan tugas-tugas kelompok meningkat. (3) motivasi dan perhatian siswa meningkat.Peningkatan hasil pembelajaran apresiasi puisi dapat dilihat dari rata-rata nilai apresiasi pratindakan $(\bar{X}=73)$ dan nilai pascatindakan $(\bar{X}=78)$.
\end{abstract}

Kata kunci: peningkatan, apresiasi, media musik

\section{IMPROVING TEACHING POEM APPRECIATION USING MUSIC MEDIA AT SMA NEGERI 11 YOGYAKARTA}

\begin{abstract}
This research tries to overcome the problem of students' difficulty in appreciating poems in the teaching process of poems and improving students' achievement of learning poem by using music media.This research is to improve the process and results of poem appreciation in learning poems applied music. The result shows the increase of the process and the result of the appreciation in learning poems. The increase of the process is shown by (1) the increase of the students activities in learning, (2) the increase of student collaboration in doing group work and (3) the increase of students motivation and attention. The increase of the result of learning poem appreciation can be seen from the average score of preactivity appreciation $(\bar{X}=73)$ and postactivition $(\bar{X}=78)$.
\end{abstract}

Keyword: improving, appreciation, music media 


\section{PENDAHULUAN}

Perkembangan kehidupan modern menempatkan musik sebagai hal yang menarik. Pertumbuhan musik telah berkembang sejak zaman dulu. Setiap daerah memiliki kekhasan musik, misalnya seperangkat gamelan untuk daerah Jawa. Musik digunakan untuk kepentingan ritual, sastra, tarian, dan mengiringi nyanyian. Namun musik jarang dipakai dalam pembelajaran Bahasa Indonesia di sekolah.

Pada masyarakat tradisional musik dipakai untuk mengiringi kesenian rakyat dan tradisi lisan. Syair, cerita di dalam tradisi lama, kerap disampaikan dan dibawakan dengan iringan musik atau dibawakan dalam lantunan tembang. Dalam perkembangan sastra modern, ada upaya memadukan dan mengisi penampilan-penampilan puisi dengan musik. Di era ini, untuk lebih membangkitkan nuansa, suasana dan daya sentuh puisi, puisi dibacakan dengan diiringi musik seperti gitar, piano, jimbe dan alat musik yang lain. Usaha kreatif memadukan musik dengan puisi ini terus berkembang hingga mencapai bentuk yang sekarang, yang kemudian mendapat nama musikalisasi puisi.

Puisi merupakan salah satu materi yang harus diajarkan di SMA. Kompetensi dasar yang ingin dicapai dalam pembelajaran puisi meliputi beberapa aspek ketrampilan, membaca, menulis, menyimak, dan berbicara, namun pada praktiknya sebagian besar pembelajaran puisi baru sampai pada aspek membaca. Pembelajaran puisi di sekolah cenderung mengajarkan pengetahuan tentang teori puisi bukan ketrampilan berpuisi.

Masalah yang menonjol pada siswa kelas XII SMA Negeri 11 Yogyakarta meliputi dua hal yaitu: kesulitan siswa dalam mengapresiasi puisi pada proses pembelajaran puisi dan hasil apresiasi puisi pada pembelajaran puisi yang belum optimal.

Tujuan penelitian ini adalah untuk mendeskripsikan aktivitas siswa dalam pembelajaran apresiasi puisi dengan media musik dan peningkatan hasil apresiasi siswa dalam pembelajaran puisi dengan media musik.

\section{METODE}

Penelitian ini menggunakan model penelitian tindakan kelas (classroom action research). Penelitian tindakan ini bersifat partisipan. Gagasan sentral penelitian ini adalah orang yang melakukan tindakan juga harus terlibat dalam proses penelitian ini dari awal sampai akhir. Penelitian menggunakan desain PTK yang dikembangkan oleh Kemmis dan Taggart, (1990, pp.11-12). Desain penelitian ini setiap siklus tindakannya meliputi perencanaan, tindakan, observasi dan refleksi. Penelitian dilakukan antara peneliti dengan guru bidang studi Bahasa Indonesia untuk meningkatkan apresiasi puisi. Penelitian ini bermaksud meningkatkan apresiasi puisi dengan media musik

Alur desain penelitian dapat dilihat pada gambar spiral penelitian tindakan sebagai berikut.

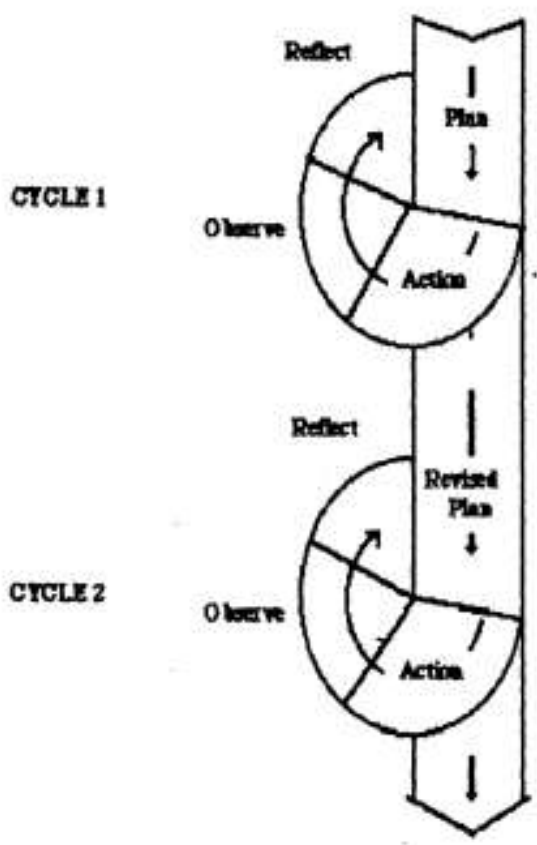

Gambar 1. Siklus Penelitian Tindakan Kelas. (Kemmis \& Taggart, 1990, p.11)

Siklus penelitian tindakan ini dilakukan dengan prosedur penelitian sebagai berikut

\section{Perencanaan}

Tahap perencanaan dimulai dari refleksi awal untuk menemukan masalah dan untuk menentukan tindakan yang akan dilakukan. Halhal yang dilakukan pada tahap perencanaan meliputi kegiatan sebagai berikut.

Peneliti bersama kolaborator, yaitu guru mata pelajaran Bahasa Indonesia kelas XII IPA1 dan rekan peneliti berdiskusi untuk mengelompokkan permasalahan yang muncul dalam pembelajaran puisi.

Pelaksanaan tindakan dalam pembelajaran puisi dengan musik dilakukan dalam bentuk siklus. Pada tahap ini perencanaan yang dibuat masih bersifat fleksibel dan terbuka terhadap perubahan dan pelaksanaannya. Tindakan dalam 
penelitian ini dihentikan apabila kemampuan mengapresiasi puisi telah mengalami peningkatan sesuai dengan target yang dinginkan.

Mengadakan pretes untuk mengetahui kemampuan awal mengapresiasi puisi. Peneliti bersama teman sejawat dan kolaborator menentukan langkah-langkah penggunaan media musik pada pembelajaran puisi.

\section{Implementasi Tindakan}

Tindakan penelitian ini berupa penggunaan media musik untuk meningkatkan apresiasi puisi dalam pembelajaran puisi. Siswa menyimak contoh musikalisasi puisi tersebut sambil mencari tema, amanat. Siswa memperhatikan lafal atau kejelasan pengucapan kata-kata. Siswa juga memperhatikan intonasi, lagu kalimat dan ekspresi atau mimik yang sesuai dengan isi puisi.

Kelompok musikalisasi dibentuk oleh siswa dan guru secara acak. Kemudian kelompok berdiskusi untuk menafsirkan isi puisi tersebut. Berdasarkan hasil penafsiran tersebut dijadikan modal untuk membuat musikalisasi puisi.

\section{Observasi.}

Observasi dilakukan untuk melakukan pemantauan terhadap kegiatan Pembelajaran Puisi di dalam dan di luar kelas. Observasi dilakukan pada saat pratindakan, siklus I, siklus II,. Hal-hal yang diobservasi terkait dengan proses belajar mengajar di dalam kelas dan di luar kelas sesuai dengan pedoman observasi. Pelaksanaan pembelajaran puisi diamati secara langsung saat proses diskusi. Observasi dilakukan berdasarkan pedoman observasi tindak belajar pada saat pelaksanaan pembelajaran puisi. Pedoman observasi memuat informasi yang terkait dengan motivasi, keaktifan, perhatian dan kerjasama siswa pada saat diskusi penjelasan dan petunjuk yang diberikan guru. Observasi dilakukan, ketika proses pembelajaran puisi berlangsung. Observasi pembelajaran puisi dengan menggunakan media musik terkait dengan proses apresiasi puisi siswa dengan media musik.

\section{Refleksi}

Pada penelitian ini refleksi dilakukan tiga tahap, yaitu (1) tahapan penemuan masalah. Pada tahap awal ini dilakukan observasi di sekolah secara keseluruhan meliputi observasi kondisi sekolah, observasi proses pembelajaran di dalam kelas, dan observasi saat dilakukan apresiasi puisi pratindakan untuk menentukan kelas mana yang akan dijadikan objek penelitian. Perbincangan dengan guru bidang studi bahasa Indonesia serta dengan beberapa siswa dilakukan untuk menggali informasi terkait dengan permasalahan yang ditemukan saat observasi. (2) tahap merancang tindakan, Adanya kendala dalam pembelajaran apresiasi puisi, memerlukan pemecahan masalah yang terkait dengan media seperti yang disebutkan oleh siswa yang diwawancarai dan guru juga menyetujuinya pada lampiran wawancara dengan guru. Penggunaan media musik perlu untuk digunakan dalam pembelajaran puisi. Hal ini diupayakan agar proses pembelajaran puisi menjadi lebih baik dan kemampuan mengapresiasi puisi sebagai hasil dari pembelajaran juga meningkat.dan (3) tahap pelaksanaan.

\section{Teknik Pengumpulan data}

Data dalam penelitian tindakan ini diperoleh dari siswa, guru, dokumen, catatan lapangan saat pelaksanaan pembelajaran dan proses kegiatan pembelajaran.

Teknik observasi yang dilakukan dalam penelitian ini adalah peneliti mengamati secara langsung proses pembelajaran puisi di dalam kelas. Observasi pertama dilakukan sebelum tindakan untuk mengetahui kondisi sekolah, khususnya kelas yang mengalami kendala dalam pembelajaran apresiasi puisi.

Catatan lapangan merupakan kelanjut-an dari kegiatan observasi. Catatan lapangan dalam penelitian ini berupa semua hal yang dilihat, didengar oleh peneliti dalam pelaksanaan pembelajaran puisi. Hal-hal yang dicatat dalam catatan lapangan meliputi proses belajar mengajar di kelas, aktivitas siswa, aktivitas guru dan instrumen pembelajaran yang ada dalam proses pembelajaran. Hal ini dilakukan saat tindakan kelas/saat kegiatan belajar mengajar apresiasi puisi berlangsung, baik pra-tindakan maupun saat tindakan

Wawancara dilakukan pada observasi pratindakan, pertengahan tindakan dan setelah tindakan. Wawancara dilakukan kepada guru dan siswa. Wawancara yang dilakukan kepada guru meliputi pertanyaan yang berkaitan dengan pembelajaran puisi di sekolah, hambatan dalam pembelajaran puisi, bagaimana cara mengatasi hambatan dalam pembelajaran puisi, Strategi yang digunakan dan media yang digunakan apa saja. Wawancara yang dilakukan kepada siswa berkaitan dengan tugas membaca dan menanggapi pembelajaran puisi di sekolah, meliputi kendala yang dialami dalam pembelajaran puisi, 
pendapat siswa setelah pembelajaran puisi dengan musikalisasi untuk meningkatkan apresiasi.

Angket diberikan kepada siswa baik sebelum maupun sesudah tindakan. Angket diberikan kepada siswa sebelum tindakan untuk mengetahui sikap dan pendapat siswa dalam kegiatan pembelajaran puisi meliputi, (a) sikap siswa pada kegiatan pembelajaran puisi, (b) kelangsungan kegiatan pembelajaran puisi di sekolah, (c) pendapat siswa mengenai membaca puisi di sekolah, (d) penggunaan musikalisasi (seperti pada lampiran angket informasi awal dalam pembelajaran puisi). Angket diberikan kepada siswa sesudah dilakukan tindakan kelas untuk memperoleh informasi mengenai sikap dan pendapat siswa terhadap peningkatan apresiasi puisi dengan musikalisasi di sekolah.

Tes dilakukan sebelum dan sesudah tindakan. Tes sebelum tindakan dilakukan untuk mengetahui kondisi awal siswa, yang dijadikan dasar untuk menghitung ada atau tidaknya peningkatan. Tes sesudah tindakan dilakukan untuk memudahkan perhitungan yang berkaitan dengan ada tidaknya peningkatan pembelajaran dan kemampuan mengapresiasi puisi siswa setelah dilakukan tindakan dengan menggunakan musikalisasi. Hasil tes dinilai dengan menggunakan pedoman penilaian yang sudah ada.

Perekaman yang dilakukan pada saat proses pembelajaran dengan menggunakan kamera. Perekaman dilakukan pada saat guru dan siswa melakukan kegiatan pembelajaran seperti kegiatan membaca, mengapresiasi di dalam dan luar kelas, kegiatan diskusi, proses pembuatan draft, merevisi, menyunting dan memublikasikan karyanya. Rekaman juga ditujukan kepada guru pada saat guru melakukan pendampingan di dalam kelas saat proses pembelajaran mengapresiasi puisi dengan media musik.

Instrumen yang digunakan dalam penelitian ini adalah guru dan kolaborator dengan cara observasi yang diwujudkan dalam lembar pengamatan. Instrumen lain yang digunakan adalah tes, pedoman penilaian, pedoman wawancara, pedoman observasi, dan pedoman catatan lapangan. Dalam rangka mendapatkan data yang lebih lengkap, maka digunakan instrumen pendukung lain berupa dokumentasi yang berwujud foto, dan rekaman atau video kegiatan pelaksanaan penelitian dari awal sampai akhir pembelajaran.

\section{Teknik Analisis Data}

Analisis data dilakukan dengan langkahlangkah model Miler dan Hubermen, 2009, p.75), sebagai berikut (1) reduksi data; (2) display/penyajian data, dan (3) mengambil kesimpulan lalu diverifikasi.

\section{Validitas dan Reliabilitas Data}

Validitas data dalam penelitian ini menggunakan model Burn dalam Madya (2007, pp.38-44) sebagai berikut.

\section{Validitas Demokratis}

Validitas ini dilakukan dalam rangka indentifikasi masalah, penentuan fokus masalah, perencanaan tindakan yang relevan, dan hal lain dari awal sampai akhir terkait dengan penelitian. Dalam hal ini, peneliti secara terbuka menerima kritik dan saran yang disampaikan oleh guru dan siswa demi menuju adanya peningkatan pembelajaran menulis cerpen.

\section{Validitas Proses}

Validitas ini dipenuhi dengan jalan peneliti dan guru bahasa Indonesia secara intensif, berkesinambungan melakukan pengamatan terhadap jalannya proses penelitian serta berkolaborasi dalam seluruh proses kegiatan yang berkaitan dengan penelitian.

\section{Validitas Hasil}

Validitas ini diupayakan melalui pengarahan orientasi dari seluruh tindakan yang dilakukan kepada tercapainya tujuan penelitian yaitu meningkatnya proses dan hasil apresiasi siswa dalam pembelajaran puisi dengan menggunakan media musik. Hasil yang dicapai siswa pada setiap siklus dianalisis. Berbagai kesalahan yang terjadi dalam setiap siklusnya diupayakan untuk dapat diatasi, sehingga hasil pada setiap akhir siklusnya dapat menjadi lebih baik.

Reliabilitas data penelitian ini dipenuhi dengan jalan menyajikan transkrip wawancara dan catatan lapangan. Catatan lapangan berupa catatan seluruh kegiatan apresiasi puisi dalam pembelajaran puisi. Untuk mendapatkan data yang sama dilakukan dengan menggunakan lebih dari satu sumber data, misalnya dengan mewawancarai guru sebagai kolaborator, mewawancarai siswa sebagai subjek penelitian, mengamati proses pengajarannya, dan merekamnya dalam bentuk foto. Hal ini selaras dengan Madya (2007, p.46)

\section{Kriteria Keberhasilan (Proses dan Hasil atau Produk)}

Proses ini dinyatakan berhasil jika ditandai dengan adanya perubahan ke arah perbaikan, 
baik terkait dengan suasana belajar dan pembelajaran. Kriteria lain adalah peningkatan prestasi belajar peserta didik dalam pembelajaran puisi yang dapat dilihat dari nilai sebelum dan sesudah tindakan.

Sehubungan dengan hal tersebut, dalam penelitian ini kriteria keberhasilan ditentukan dengan menggunakan kriteria evaluasi yang bersifat absolut, yaitu tindakan dibandingkan dengan standar minimal keberhasilan yang telah ditentukan. Apabila hasil tindakan sesuai dengan standar minimal yang telah ditentukan, tindakan dinyatakan berhasil dengan baik (Djamarah dan Zain, 1996, p.122). Adapun standar minimal yang ditentukan adalah $60-70 \%$ dari jumlah siswa yang mengikuti proses belajar mengajar telah mencapai taraf keberhasilan minimal. Selanjutnya untuk memberikan makna terhadap peningkatan kualitas yang bersifat normatif, yaitu apabila keadaan setelah dilakukan tindakan lebih baik dari sebelumnya, maka tindakan tersebut dinyatakan berhasil dengan baik, tetapi bila keadaan lebih buruk dari sebelumnya belum dinyatakan berhasil.

\section{HASIL DAN PEMBAHASAN}

Berdasarkan observasi penelitian yang dilakukan sebelum penelitian, didapatkan beberapa informasi terkait dengan SMA 11 Yogyakarta, pembelajaran puisi diperoleh hasil observasi pratindakan diketahui bahwa 1) siswa saat mendapat tugas mengapresiasi puisi adalah sebagai berikut: ada anak yang menunjuk temannya, "Dia saja, Pak. Dia sering baca puisi jadi pinter kalau suruh komentar", itulah kalimat yang dilontarkan pada guru. Ada juga yang bilang "Ah susah, Pak baca puisi." Masih saja siswa yang berkomentar "Males, Pak monoton gitu-gitu aja puisi." Ada yang diam tak bereaksi, ada yang pasif terhadap pelajaran puisi. Setiap kali ada penampilan membacakan puisi yang maju selalu siswa yang sama. bahkan tidak jarang justru siswa tersebut memberikan keluhan lain yang memancing terjadinya suasana gaduh.

Wawancara dengan guru diperoleh informasi bahwa (1) masih ada siswa yang belum mampu berbicara memberikan apresiasi puisi dengan baik; (2) waktu yang tersedia kurang; (3) siswa kurang memiliki minat terhadap pelajaran Bahasa Indonesia, dan (4) adanya pandangan dari beberapa siswa bahwa pelajaran Bahasa Indonesia itu kurang serius karena dianggap mudah tak ada tantangan serta kurang bergengsi dibanding dengan pelajaran yang lain.
Angket kepada siswa memberikan informasi bahwa siswa yang tidak menyukai kegiatan mengapresiasi (membaca dan menanggapi pembacaan), siswa mengaku kegiatan membaca puisi dilakukan di dalam kelas saja, siswa mengaku tidak senang mendapatkan tugas praktik membaca puisi di sekolah, siswa menga$\mathrm{ku}$ membaca dan mengapresiasi puisi adalah kegiatan yang sulit, siswa memberikan informasi bahwa media yang digunakan baru sebatas buku (teks puisi) dan pulpen, lingkungan sekitar sekolah belum pernah dimanfaatkan sebagai media mengapresiasi puisi.

Pelaksanaan pembelajaran puisi sebelum menggunakan media musik yaitu guru hanya menggunakan metode ceramah, tanya jawab dan tugas dalam pembelajaran puisi. Berdasarkan hasil wawancara yang dilakukan dengan guru dalam menyampaikan materi puisi menggunakan metode tersebut dan ditambah dengan bantuan materi dari buku paket yang digunakan pembelajaran di kelas.

Guru menyampaikan materi ajar puisi dengan memperkenalkan contoh puisi baru, siswa mendengarkan.Guru memberi penjelasan tentang unsur intrinsik puisi, siswa mendengarkan.Guru membacakan puisi, siswa mendengarkan. Guru meminta salah satu siswa untuk membaca puisi. Siswa diminta untuk mengomentari penampilan teman (lisan). Siswa diminta mencari unsur intrinsik puisi (tertulis).Siswa diminta untuk memparafrasekan puisi tersebut dengan kalimat sendiri (tertulis). Siswa berjumlah 36 orang setelah selesai yang mengumpulkan hasil evaluasi tertulis puisi yang dilakukan sebelum menggunakan media musik. Guru bersama peneliti menilai bersama hasil kerja siswa dalam mengapresiasi puisi sebelum menggunakan media musik. Pada pembelajaran puisi tersebut siswa nampak pasif dan masih berpusat pada guru. Siswa kurang begitu tertarik dan kurang berminat untuk mengikuti pembelajaran puisi. Hal ini bisa dilihat dari hasil pengamatan dan terbukti lewat analisis hasil pekerjaan siswa yang hasilnya belum maksimal.

Hasil kerja siswa terlihat sudah cukup baik, namun tugas memparafrasekan atau mengapresiasi dengan bahasanya sendiri belum kelihatan berani. Hal ini akan diupayakan untuk ditingkatkan. Peningkatannya diupayaan dengan menggunakan media musik.

Pembelajaran apresiasi puisi sebelum menggunakan media musik puisi terlihat anak kurang aktif dan kurang bisa mengoptimalkan keberanian mengungkapkan pendapat, ide, 
gagasan sebagai apresiasi terhadap puisi maupun penampilan baca puisi. Hal ini menunjukkan bahwa siswa perlu diberi suasana yang baru dalam pembelajaran puisi dengan menggunakan media musik.

Berdasarkan temuan saat observasi, angket, wawancara peneliti dengan guru dan siswa tersebut di atas, maka diperlukan solusi kepada siswa adalah dengan media musik.

Tes apresiasi puisi berupa mengapresi-asi puisi berbentuk esai adalah sebagai berikut. Siswa, (1) dalam menyelesaikan tugas mengapresiasi terlihat lambat dalam waktu dua jam pelajaran ( 2 x 45 menit) hanya sebatas membaca teks puisi, kemudian mengapresiasinya dengan memparafrasekan dan mengomentari pembacaan puisi. (2) melakukan kegiatan apresiasi puisi tanpa ada kreativitas imajinasi yang berarti. (3) Siswa tanpak tidak memiliki motivasi untuk membaca, memahami dan mengapresiasi puisi. (4) Siswa dalam mengerjakan tugas apresiasi dilakukan tanpa diskusi dan kerja sama, tidak direvisi, tidak di-edit dan juga tidak dipublikasikan. Berdasarkan hasil apresi-asi diketahui adanya siswa mengapresiasi puisi masih dipermukaan saja belum sampai memaknai secara mendalam isi puisi dengan intens.

Proses pembelajaran apresiasi puisi pada tahap ini dilakukan tanpa proses diskusi kelompok, dan hanya sebatas proses membaca saja, tanpa ada variasi lain membuat siswa mengalami kebosanan dan kejenuhan. Proses yang tidak maksimal dalam pembelajaran ini membuat siswa tidak kreatif. Hal ini mengakibatkan siswa tidak bisa secara lebih mendalam mengapresiasi puisi, sebagai contoh parafrase dan dengan puisi dari nomor urut 15, 20, 23, 24, 35 banyak coretan dan goresan tipe-ex ditemukan dalam lembar kertas tugasnya. Selain itu, ditemukan juga siswa yang belum percaya diri terhadap parafrase yang dibuat. Hal ini diindikasikan dengan menulis menggunakan pensil yang ditemukan pada nomor urut 1, 2, 3, 6, 12, 13, 16, 21. Hal ini menunjukkan bahwa anak tersebut penuh keraguan dalam menuliskan apresiasi yang dilakukannya. Banyak juga ditemukan coretan dan kata yang diselipkan. Hal itu ditemukan pada parafrase nomor 8 . Banyak juga kalimat yang masih datar dan asal berkomentar. Hal itu dapat dilihat pada komentar siswa nomor urut 9.

Gambar 2 berikut ini merupakan grafik perolehan nilai apresiasi puisi saat pratindakan.

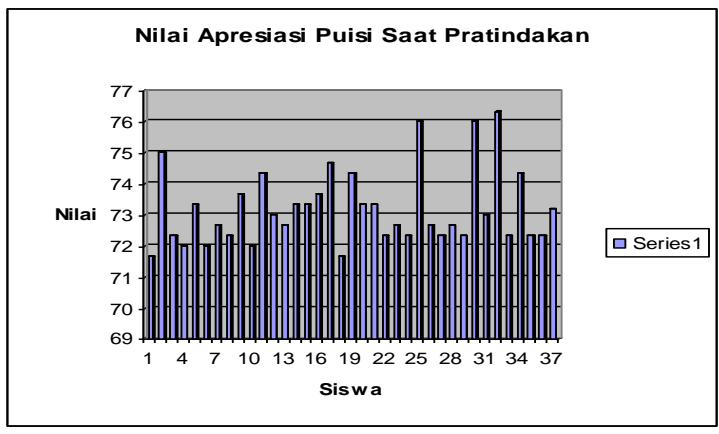

Gambar 2. Hasil Penelitian Siklus 1

Permasalahan siswa belum memiliki motivasi, perhatian, dan keaktifan dalam melaksanakan proses apresiasi puisi. Hal ini dijadikan acuan dalam perencanaan penelitian tindakan. Siklus 1, dilaksanakan sesuai dengan rencana yaitu siswa (1) diberikan contoh musikalisasi dari sekolah lain, (2) diberikan teks puisi berjudul Sepenggal Syair untuk Laut, (3) diminta untuk membaca puisi tersebut dalam hati, (4) diminta memahami isi puisi tersebut, (5) saat publikasi diminta untuk memberikan sentuhan musik agar menarik.

Guru dalam apersepsi direncanakan memberikan pengarahan tentang musikalisasi puisi. Hal ini dilakukan antara lain dengan memberikan contoh rekaman puisi yang ditampilkan dengan musikalisasi.

Pelaksanaan siklus I pertemuan pertama dilaksanakan pada hari Kamis, 4 November 2010. Proses pelaksanaan tindakan dalam penelitian ini, adalah sebagai berikut, (a) siswa memperhatikan arahan guru di kelas, (b) siswa memperhatikan ulasan dari guru terkait dengan pertemuan sebelumnya, (c) siswa memperhatikan petunjuk kerja yang disampaikan oleh guru, (d) diskusi antara guru bersama siswa pun dilakukan untuk menampung segala macam kendala yang dirasakan oleh siswa. Kendala yang dimaksud terkait dengan kesulitan yang dialami selama melakukan pembelajaran apresiasi puisi di kelas.

Pada siklus 1, dilaksanakan dengan peneliti masuk ke dalam kelas, dan mengkondisikan siswa untuk siap mengikuti materi yang disampaikan, dengan Silabus dan RPP yang telah direncanakan pada siklus 1. Pelaksanaan pembelajaran puisi pada siklus 1 berlangsung 90 menit.

\section{Kegiatan Awal (10 Menit)}

Guru menanyakan siswa yang pernah mengikuti lomba musikalisasi puisi, deklamasi atau pembacaan puisi. Bila ada, siswa yang 
bersangkutan diminta untuk menceritakan (sharing) pengalamannya saat berlomba atau menbuat musikalisasi puisi tersebut Guru memutarkan VCD atau rekaman contoh musikalisasi puisi.Siswa memberikan ulasan atau komentar singkat.

\section{Kegiatan Inti (60 Menit)}

Siswa duduk dalam kelompok-kelompok kecil yang terdiri atas 7 orang anggota. Guru membagikan sebuah puisi berjudul Sepenggal Syair untuk Laut karya Dorothea Rosa Herlyani. Guru memberikan penjelasan tentang aspekaspek yang harus diperhatikan dalam musikalisasi puisi yang akan dikerjakan oleh siswa. Guru memberikan penjelasan mengenai musikalisasi di sini sebagai sebagai media pengantar pemahaman apresiasi puisi. Guru menjelaskan lafal, intonasi, artikulasi, dan ekspresi yang merupakan aspek penting dalam pembacaan/ penampilan musikalisasi. Setelah berkelompok siswa diskusi untuk menggarap puisi dalam sebuah komposisi musik/lagu, guru melakukan pengamatan atas kerja yang dilakukan siswa. Setelah proses pembuatan musikalisasi puisi dianggap cukup masing-masing kelompok mempresentasikan karya musikalisasi puisi yang telah dibuat.

Siswa kelompok lain menyaksikan dan mengamati presentasi yang dilakukan oleh temannya. Secara bergiliran masing-masing kelompok memberikan tanggapan atau komentarnya tentang atas penampilan musikalisasi puisi yang baru saja ditampilkan teman. Tanggapan yang diberikan mengarah kepada unsur komposisi lagu, harmonisasi, lafal, intonsai, artikulasi dan ekspresi, guru mengamati dan mencermati isi serta bahasa tanggapan siswa. Guru memberikan ulasan atas tanggapan siswa. Beberapa tanggapan yang bagus diberi pujian. Jika perlu, guru menampilkan lagi karya musikalisasi puisi yang dikomentari siswa dan guru paling baik. Kegiatan pembelajaran ini bertujuan meningkatkan apresiasi puisi siswa kelas XII IPA1. Siswa juga memiliki motivasi, perhatian, dan keaktifan dalam menjalankan proses apresiasi puisi. Adapun tindakan yang dilakukan oleh peneliti bersama kolaborator pada pertemuan pertama siklus I, sebagai berikut.

\section{Apersepsi}

Kegiatan awal guru mengajak siswa untuk berdoa bersama, menanyakan kabar, dan ada tidaknya siswa yang tidak masuk sekolah atau absen. Guru memberikan pengantar mengenai kegiatan yang akan berlangsung, apresiasi puisi dengan musikalisasi puisi.

\section{Musik sebagai Media Apresiasi Puisi}

Guru mengkondisikan siswa kelas XII IPA 1 untuk memperhatikan contoh penampilan siswa sekolah lain dalam melakukan apresiasi puisi dengan cara musikalisasi puisi (dalam bentuk video rekaman). Hal ini dilakukan agar siswa memiliki gambaran terhadap musikalisasi puisi. Kelas ini belum familier dengan istilah musikalisasi puisi (Lampiran angket akhir pertanyaan nomor 2 . Berdasarkan video yang diputar di kelas terlihat bahwa musikalisasi dilakukan secara berkelompok, ada yang menjadi vokal, ada yang mengiringi musik.

\section{Pembentukan Kelompok}

Pemutaran video rekaman musikalisasi puisi telah selesai, maka siswa kelas XII IPA 1 dimintai untuk membuat kelompok, disarankan setiap kelompok ada yang bisa bermain musik. Pembentukan kelompok telah selesai, kemudian guru memberikan teks puisi di masing-masing kelompok.

\section{Pengarahan dari Guru}

Semua kelompok sudah memiliki teks puisi yang dibagikan oleh guru. Guru memberikan pengarahan mengenai langkah-langkah melakukan kegiatan apresiasi puisi. (a) membaca puisi, (b) mengapresiasi puisi, (c) memaknai puisi, (d) membuat parafrase puisi, (e) membuat senandung puisi, (f) membuat iringan pembacaan puisi dengan alat-alat yang sudah dipilih dan dimiliki. Alat musik yang digunakan adalah alat musik yang berasal dari peralatan rumah tangga dan barang bekas (perkusi). Alat itu meliputi botol air minum bekas, kaleng bekas, panci, sendok, garpu, sendok, dan galon air minum. Beberapa botol diisi biji-bijian yang berbeda-beda. Botol tersebut akan menghasilkan suara yang unik.

Kelompok satu mengunakan alat musik berupa gitar, kaleng cat, kaleng permen Tanggo diisi beras. Kelompok dua mengunakan alat musik berupa orgen, plastik tempat makan dan galon air minum diisi pasir. Kelompok tiga mengunakan alat musik berupa gitar, tempat minum diisi kacang hijau, botol air minum diisi beras, keyboard atau orgen.

\section{Diskusi Kelompok}

Pada rangkaian kegiatan kali ini, siswa dalam kelompok membaca puisi, memahami, 
menentukan kunci dan jenis iringan musik yang diinginkan. Pada kegiatan kali ini setiap kelompok sudah menunjuk anggota kelompok yang akan menggiringi musik, dan siapa yang akan menjadi backing vocal-nya. Kegiatan selanjutnya meng-aranssement-nya sambil berlatih membaca puisi dengan media musik.

Latihan Musikalisasi

Pada tahap ini, semua kelompok mendapatkan kesempatan yang sama untuk berlatih menampilkan puisi. Kegiatan latihan ini belum dinilai, karena masih ada beberapa kekurangan yang penting untuk diperbaiki. Latihan berlangsung, setiap kali ada kelompok yang tampil, kelompok lain siap memberikan saran untuk kebaikan kelompok yang tampil. Semua harus berlaku fair artinya kalau ada yang memberikan saran harus diterima, begitu juga saat memberikan saran harus disertai dengan alasan yang logis.

vokal, tidak ada penghayatan, masih monoton, dan pembagian waktu yang tidak tepat karena ketika diskusi berlarut-larut tak terasa waktu habis. Saat dipublikasikan di depan kelas banyak yang bilang belum siap.

Pembelajaran puisi dengan media musik pada siswa kelas XII A1 telah dilakukan sebanyak 2 siklus. Pembelajaran itu telah meningkatkan apresiasi siswa terhadap puisi. Siklus 1 dan Siklus 2 dilakukan sesuai dengan rencana. Siklus 2 merupakan perbaikan dari siklus 1 . Hal ini dilakukan untuk memperbaiki kelemahan yang ada pada siklus 1 .

Siklus 1 dilakukan mulai perencanaan sampai refleksi. Aktivitas siswa dilakukan di dalam kelas sesuai jadwal yang ada. Tindakan dilakukan secara bertahap untuk mendapatkan hasil yang maksimal. Siklus 1 dirancang oleh peneliti dan dalam pelaksanaannya berbeda dengan guru sebelum musikalisasi puisi. Pada siklus ini peneliti terjun langsung dalam pembelajaran puisi bersama guru sebagai kolaborator.

\section{Observasi}

Berdasarkan pengamatan yang dilakukan terlihat bahwa siswa mulai tertarik, antusias terhadap pelajaran apresiasi puisi dan berani memberi tanggapan. Hal ini terlihat dari siswa yang menggambil bagian dalam kelompoknya untuk menyelesaikan tugas kelompok. Ada yang dengan suka rela menjadi sekretaris, ada yang menjadi ketua ada yang menjadi pengarah musik, ada pengkoordinir semua kegiatan dalam kelompok. Semangat itu terlihat dari aksentasi siswa pada kegiatan apresiasi puisi. Kegiatan apresiasi ini, terlihat semua siswa aktif dalam kelompoknya. Sebagai bahan pertimbangan dapat dilihat dalam catatan lapangan dan foto kegiatan pada lampiran.

Refleksi

Tahap refleksi dilakukan analisis hasil tindakan pada siklus 1. Pada siklus satu ditemukan beberapa hambatan diantaranya: (a) siswa sulit menemukan aransemen musik yang sesuai, (b) menentukan alat musik yang akan dipakai, (c) waktu yang belum digunakan secara efektif.

Pembelajaran sastra puisi pada siklus I, telah direncanakan menggunakan media musik. Pertemuan I pembelajaran sastra puisi, diawali dengan kegiatan siswa untuk memperhatikan petunjuk dan penjelasan guru terkait dengan musikalisasi puisi. Alur kerja siswa dalam melaksanakan tugas ini pada tahap dilakukan secara berkelompok, sedangkan untuk kegiatan membuat parafrase dilakukan secara mandiri. Tahap publikasi dilakukan dengan menampilkan musikalisasi puisi. Guru berperan sebatas sebagai pemantau dan pendamping kegiatan siswa di dalam kelas. Media yang digunakan sebagai alat musik dalam tindakan kali ini adalah alat musik dari barang-barang bekas.

Evaluasi yang dilakukan dalam penelitian ini meliputi evaluasi menulis yang berupa menulis parafrase puisi dan hasil dari musikalisasi puisi. Musikalisasi di sini sebagai produk hasil mengapresiasi puisi. Berdasarkan parafrase tersebut, kemudian dinilai sesuai dengan standar penilaian yang ada. Penelitian ini diadakan dua macam evaluasi, yaitu: (1) evaluasi berdasarkan standar minimal dengan tujuan jangka pendek yang dilakukan pada setiap akhir tindakan, dengan tujuan mengetahui keberhasilan dalam satu kali tindakan. Penelitian ini memiliki tujuan jangka pendek berupa siswa mendapatkan nilai rata-rata minimal sebesar 75,00. (2) Evaluasi didasarkan pada prestasi belajar apresiasi sebelum dilakukan tindakan, dibandingkan dengan kondisi sesudah dilakukan tindakan kelas. Perbandingan ini akan memberikan informasi tentang terjadinya peningkatan atau tidak. 


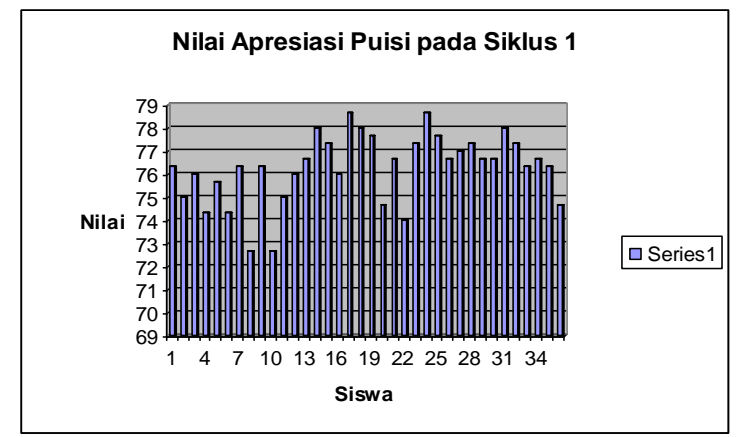

Gambar 3.

Hasil evaluasi yang didapat dari siswa pada siklus 1 mengalami banyak peningkatan yaitu dengan nilai rata-rata siswa 76,3. Siswa yang memperoleh nilai di atas rata-rata ada 29 orang siswa. Penilaian kali ini diperoleh nilai tertinggi 79. Ada dua orang siswa yang memperoleh nilai 79. Nilai terendah 73 diperoleh satu orang siswa. Hal ini disebabkan kemampuan siswa dalam mengapresiasi dan kerja sama dengan teman masih kurang. Meskipun begitu, sikap yang ditunjukkan oleh siswa adalah mulai tumbuhnya antusias untuk mengikuti pembelajaran puisi dengan musikalisasi. Hal tersebut sudah mulai terlihat, ketika siswa diminta mengaransemen lagu, maka otomatis siswa harus membaca berulang-ulang puisi tersebut. Siswa juga termotivasi bahwa nanti musikalisasi ini akan ditampilkan. Siswa terlihat aktif diskusi dengan temannya untuk mewujudkan musikalisasi. Siswa yang malu-malu kalau tampil sendiri kelihatan lebih berani karena tampil berkelompok.

\section{Revisi Rancangan Tindakan}

Berdasarkan refleksi di atas dapat disimpulkan bahwa siswa sulit (1) menemukan aransemen musik yang sesuai, (2) menentukan alat musik yang akan dipakai, (3) waktu belum digunakan secara efektif, (4) memahami puisi, (5) mengerti apa yang dimaksud pengarang. Berdasarkan hal tersebut pada siklus 2 direncanakan pembelajaran dilakukan dengan mengadakan pembaharuan seperti (1) puisi yang digunakan diganti dengan puisi Sajak Atas Nama, (2) waktu yang digunakan ditambah 1 jam; (3) alat musik diberikan tambahan variasinya dan (4) diberikan arahan tentang aransemen musik.

Penggantian puisi di atas dimaksudkan agar tidak bias. Apabila puisi pada siklus 1 dan 2 sama bisa jadi peningkatan yang terjadi karena puisinya sama, namun apabila puisi berbeda tetapi hasilnya terjadi peningkatan ini artinya memang media musik benar dapat meningkatkan pembelajaran apresiasi puisi.

\section{Simpulan Siklus I}

Berdasarkan proses pembelajaran apresiasi puisi yang berlangsung diketahui bahwa tingkat antusiasme siswa terhadap pembelajaran puisi meningkat. Hal ini diindikasikan setiap anak melakukan proses pembelajaran tanpa dengan keluhan, segera menyelesaikan apa yang menjadi arahan guru, wajah riang mengekspresikan kesenangan terhadap pelajaran tersebut, sungguh melekukan parafrase, dan aransemen puisi ke dalam musik

Berdasarkan pelaksanaan pembelajaran diketahui nilai rata-rata adalah 76 . Nilai tertinggi 76, nilai terendah 71. Siswa sejumlah 36 orang yang mencapai nilai rata-rata ada 4 orang siswa sisanya masih di bawah KKM.

\section{Hasil Siklus II}

\section{Perencanaan}

Permasalahan siswa belum memiliki motivasi, perhatian, dan keaktifan dalam melaksanakan proses apresiasi puisi. Hal ini dijadikan acuan dalam perencanaan penelitian tindakan. Siklus 1, dilaksanakan sesuai dengan rencana yaitu siswa (1) diberikan contoh musikalisasi dari sekolah lain, (2) diberikan teks puisi berjudul Sajak Atas Nama, (3) diminta untuk membaca puisi tersebut dalam hati, (4) diminta memahami isi puisi tersebut, (5) saat publikasi diminta untuk memberikan sentuhan musik agar menarik.

Guru dalam apersepsi direncanakan memberikan pegarahan tentang musikalisasi puisi. Hal ini dilakukan antara lain dengan memberikan contoh rekaman puisi yang ditampilkan dengan musikalisasi.

\section{Pelaksanaan}

Siklus 2 dilakukan mulai perencanaan sampai refleksi. Aktivitas pembelajaran dipindah di aula untuk pementasan, dengan beberapa catatan hambatan yang ada pada siklus 1 , dijadikan evaluasi pada siklus 2, Tindakan dilakukan untuk mencapai nilai yang maksimal.

Pelaksanaan siklus 2 guru perlu bersifat fleksibel dalam hal pengelolaan waktu. Apabila waktu yang tersisa untuk kegiatan ini tidak mencukupi, pekerjaan dapat dilanjutkan di rumah. Kegiatan ini pun dapat disatukan dengan tugas luar kelas. Perlu ditekankan bahwa siswa tidak melakukan plagiatisme dengan mengambil sajak orang lain dan mengakui sebagai miliknya. Guru 
juga perlu mengingatkan bahwa tujuan pelajaran ini bukanlah untuk menciptakan penyair yang mampu mengekspresikan puisi dengan baik. Kegiatan ini sebagai salah satu kegiatan bermusik yang dikombinasikan dalam pembelajaran apresiasi puisi. Tujuannya agar siswa memiliki wawasan lain yang mana apresiasi puisi dapat dilakukan dengan cara yang mengasyikkan, dapat menghibur dan mengendurkan pikiran.

Kegiatan ini adalah tindak lanjut dari proses produktif tersebut, siswa diberi waktu satu minggu untuk menyelesaikan karyanya tersebut. Karya tersebut dikumpulkan dalam bentuk keping $\mathrm{CD}$, sehingga ada dokumentasi karya musikalisasi dan untuk penilaian tugas mandiri tidak terstruktur secara berkelompok. Ada baiknya juga siswa membentuk suatu tim kreatif khusus untuk mengerjakan pembuatan keping CD ini. Manfaat dari "proyek" semacam ini adalah pada acara seperti pameran, bazar, open house, dan semacamnya, kreasi siswa ini dapat diperlihatkan. Lebih baik lagi apabila kegiatan musikalisasi ini dapat juga menumbuhkan minat kreatif siswa. Guru menilai yang sifatnya mengapresiasi hasil kerja siswa, tetapi juga boleh mengumpulkannya tanpa memberi nilai. Hasilnya dapat disimpan di perpustakaan atau laboratorium bahasa.

\section{Observasi}

Berdasarkan pengamatan yang dilakukan terlihat bahwa siswa mulai tertarik, antusias terhadap pelajaran apresiasi puisi dan berani memberi tanggapan. Hal ini terlihat dari siswa yang menggambil bagian dalam kelompoknya untuk menyelesaikan tugas kelompok. Ada yang dengan sukarela menjadi sekretaris, ada yang menjadi ketua ada yang menjadi pengarah musik, ada pengkoordinir semua kegiatan dalam kelompok. Semangat itu terlihat dari aksentasi siswa pada kegiatan apresiasi puisi. Kegiatan apresiasi ini, terlihat semua siswa aktif dalam kelompoknya. Sebagai bahan pertimbangan dapat dilihat dalam catatan lapangan dan foto kegiatan pada lampiran.

Refleksi

Pada siklus satu ditemukan beberapa hambatan diantaranya: (a) siswa sulit menemukan aransemen musik yang sesuai, (b) menentukan alat musik yang akan dipakai, (c) waktu yang belum digunakan secara efektif.

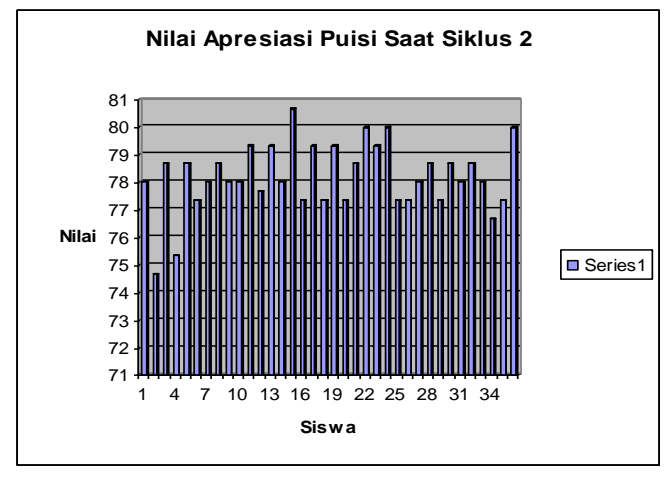

Gambar 4.

Hasil evaluasi yang didapat dari siswa pada siklus 2 mengalami banyak peningkatan yaitu dengan nilai rata-rata siswa 78 . Siswa yang memperoleh nilai di atas rata-rata ada 36orang siswa. Penilaian kali ini diperoleh nilai tertinggi 81. Ada satu orang siswa yang memperoleh nilai 81. Nilai terendah 75 diperoleh satu orang siswa. Hal ini disebabkan kemampuan siswa dalam mengapresiasi dan kerjasama dengan teman masih kurang. Meskipun begitu, sikap yang ditunjukkan oleh siswa adalah mulai tumbuhnya antusias untuk mengikuti pembelajaran puisi dengan media musik.

\section{Revisi Rancangan Tindakan}

Berdasarkan refleksi di atas dapat disimpulkan bahwa siswa sulit (1) menemukan aransemen musik yang sesuai, (2) menentukan alat musik yang akan dipakai, (3) waktu belum digunakan secara efektif. Berdasarkan hal tersebut pada siklus 2 direncanakan pembelajaran dilakukan dengan mengadakan pembaharuan seperti (1) puisi yang digunakan diganti dengan puisi Sajak Atas Nama, (2) waktu yang digunakan ditambah 1 jam; (3) alat musik diberikan tambahan variasinya dan (4) diberikan arahan tentang aransemen musik.

\section{Simpulan Siklus 2}

Berdasarkan proses pembelajaran puisi yang berlangsung diketahui bahwa tingkat antusiasme siswa terhadap pembelajaran puisi meningkat. Hal ini diindikasikan setiap anak melakukan proses pembelajaran tanpa dengan keluhan, segera menyelesaikan apa yang menjadi arahan guru, wajah riang mengekspresikan kesenangan terhadap pelajaran tersebut, sungguh melakukan parafrase, dan aransemen puisi ke dalam musik. Pada siklus ini siswa diberikan teks puisi yang sama ditiap kelompok. Hal yang membedakan adalah semua kelompok diwajibkan mengaransemen teks puisi ke dalam musi- 
kalisasi puisi. Jadi apresiasi puisi yang dilakukan diimplementasikan pada musikalisasi puisi. Musikalisasi puisi harus dipresentasikan di depan teman di kelas. Hal ini dimaksudkan teman sekelas dapat memberikan penilaian, saran dan sebagainya. Musikalisasi puisi adalah produk apresiasi puisi. Penentu keberhasilan dalam penelitian ini adalah meningkatan nilai rata-rata kelas di atas KKM.

\section{Pembahasan}

\section{Proses Apresiasi Pratindakan}

Berdasarkan hasil observasi sebelum menggunakan media musik, guru menyampaikan materi puisi dengan menggunakan metode ceramah, metode tanya jawab, dan pemberian tugas. Metode ceramah mendominasi pembelajaran, sehingga terpusat kepada guru. Pada saat guru menjelaskan materi, siswa mendengarkan. Guru juga memberikan contoh cara membaca puisi. Setelah guru menjelaskan materi dan memberi contoh membaca puisi, siswa diberi kesempatan bertanya. Siswa menjadi pasif karena beberapa alasan: (1) siswa malu untuk bertanya, (2) siswa kurang tertarik dengan materi puisi, (3) siswa tidak paham materi yang diajarkan. Metode ceramah dan tanya jawab ini berlangsung selama 90 menit. Pemberian tugas pada siswa dilakukan oleh guru pada akhir penyampaian materi.

Guru menggunakan metode ceramah karena metode ini merupakan metode yang umum digunakan ketika guru menyampaikan materi. Selain itu metode ini juga digunakan dengan maksud agar peneliti dapat membandingkan antara hasil apresiasi puisi pada pembelajaran puisi sebelum menggunakan media musik dengan hasil pengajaran puisi dengan menggunakan media musik. Langkah-langkah yang dilakukan guru dalam menyampaikan materi pembelajaran puisi adalah (a) Pembukaan, (b) Penyampaian Materi, (c) penutup.

Hasil Penelitian Siklus 1

Permasalahan siswa belum memiliki motivasi, perhatian, dan keaktifan dalam melaksanakan proses apresiasi puisi. Berdasarkan hasil tes dan proses pembelajaran diketahui bahwa sudah memenuhi harapan, namun dari segi proses kurang fokus, tidak jarang ditemui siswa masih kurang koheren antara aransemen musik dan isi puisi, bahkan ditemukan beberapa kelompok yang belum bisa menganalisis puisi dan mengembangkan ide serta imajinasi dise- suaikan dengan musik yang diinginkan. Banyak ditemukan adanya kesalahan, penciptaan kesan pada pendengar kurang. Penguasaan alat musik yang tidak merata dan masih banyak ditemukan kesalahan. Misalnya kurang kompak antara musik dan vokal, tidak ada penghayatan, masih monoton, dan pembagian waktu yang tidak pas karena ketika diskusi berlarut larut tak teras waktu habis. Saat dipublikasikan di depan kelas banyak yang bilang belum siap.

\section{Hasil Apresiasi Puisi Siklus II}

Siklus 2 dilaksanakan pada 11 November 2010. Nilai yang didapat dari siswa pada siklus 2 mengalami banyak peningkatan yaitu dengan nilai rata-rata siswa 78. Siswa yang memperoleh nilai di atas rata-rata ada 36 orang siswa. Nilai tertinggi yang diperoleh kali ini 81. Ada dua orang siswa yang memperoleh nilai 81. Nilai terendah 75 diperoleh satu orang siswa. Hal ini disebabkan kemampuan siswa dalam mengapresiasi dan kerjasama dengan teman masih kurang. Meskipun begitu, sikap yang ditunjukkan oleh siswa adalah mulai tumbuhnya antusias untuk mengikuti pembelajaran puisi dengan musikalisasi. Hal tersebut sudah mulai terlihat, ketika siswa diminta mengaransemen lagu, maka otomatis siswa harus membaca berulang-ulang puisi tersebut. Siswa juga termotivasi bahwa nanti musikalisasi ini akan ditampilkan. Siswa terlihat aktif diskusi dengan temannya untuk mewujudkan musikalisasi. Siswa yang malumalu kalau tampil sendiri kelihatan lebih berani karena tampil berkelompok.

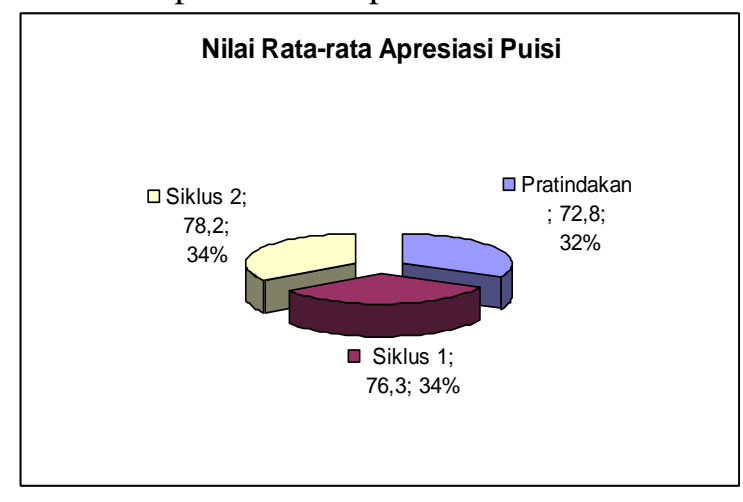

\section{Gambar 5}

Media Musik dapat mempermudah dan memberikan kebermaknaan siswa dalam apresiasi puisi dan berimajinasi dengan cepat dan mudah. Media Musik dapat membantu meningkatkan apresiasi puisi, karena siswa ditantang untuk dapat membaca puisi dengan benar, kreatif dan memadukan dengan musik secara tepat, sehingga siswa mampu mengapresiasi 
puisi dengan pemaknaan yang tepat. Hal ini dapat meningkatkan keaktifan siswa dan membuat antusias siswa terhadap pembelajaran puisi. Selanjutnya terjadi peningkatan minat siswa dalam mengapresiasi puisi secara benar.

Waktu dan tempat penelitian bulan November 2010 sampai dengan April 2011 di SMA Negeri 11 Yogyakarta.

\section{SIMPULAN}

Pembelajaran puisi dengan menggunakan media musik mengalami peningkatan pada proses dan hasil. Peningkatan proses apresiasi puisi ditandai dengan meningkatnya semangat, perhatian, dan keaktifan siswa dalam setiap tahapan apresiasi puisi. Hal ini diindikasikan dengan (1) siswa termotivasi untuk membaca teks puisi yang diberikan. (2) siswa memiliki semangat membuat parafrase teks puisi yang diberikan. (3) siswa memiliki semangat untuk memahami teks puisi yang diberikan.(4) siswa mempunyai perhatian terhadap membuat parafrase, (5) siswa aktif membuat aransemen puisi dan menampilkan musikalisasi puisi.

Peningkatan hasil apresiasi puisi ditandai dengan adanya peningkatan nilai rata-rata 73 pada pratindakan menjadi 76 pada siklus I dan menjadi 78 pada siklus II. Hasil apresiasi puisi menunjukkan (1) adanya peningkatan yang awalnya nilai rata di bawah KKM, setelah dilakukan tindakan menjadi melebihi KKM. (2) siswa yang mendapatkan nilai melebihi KKM pada siklus 1 mencapai $80 \%$, pada siklus 2 mencapai $100 \%$. Berdasarkan hal inilah dapat dikatakan bahwa hasil berupa nilai telah melebihi standar minimal keberhasilan. Penggunaan media musik dapat meningkatkan hasil dan proses pembelajaran apresiasi puisi dalam pembelajaran puisi.

\section{DAFTAR PUSTAKA}

Ari KPIN. (2008). Musikalisasi puisi. Yogyakarta: Hikayat Publishing.

Djamarah, Syaiful Bahri dan Zain, Aswan. (1997). Stategi belajar mengajar. Jakarta: Rineka Cipta.

http://lib.atmajaya.ac.id/default.aspx?tabID=61 $\& s r c=k \& i d=151593$

Iskandar. (2009). Penelitian tindakan kelas. Ciputat: Gaung Persada Press.

Kemmis, S \& McTaggart, R. (1990). The action research planner. Victoria: Deaken University Press

Ksatrio, Budhi. (2008). Hubungan antara kemampuan bermusik dengan kemampuan matematika pada murid SD (Penelitian pada murid kursus piano sekolah music ABS). Diambil tanggal 21 Maret 2010, dari

Madya, Suwarsih.(2007) Teori dan praktik penelitian tindakan. Bandung: Alfabeta. 